общество, для почвенников стало превращение принудительно управляемого сообщества в свободную, соборную общину верующих, церковь.

Идеи почвенничества, интерпретированные в контексте современных глобальных социальнополитических процессов, оказываются очень актуальными. Если почвенники призывали к освобождению всех славянских народов от угнетения Османской империи в XIX веке, то сейчас оно звучит как освобождение от свободы западноевропейского образца. Создание соборной общины «верующих народов» вполне укладывается в концепцию развития ответственного гражданского общества с неутраченными национальными традициями, культурой и нравственными устоями, которые помогают жить социуму в цивилизованных добрососедских условиях. Разумеется, это наше достаточно схематичное предположение концептуализации идей почвенничества в современных условиях.

\section{Список литературь}

1. Богданов А. В. Политическая теория почвенничества : дис. ... канд. полит. наук: 23.00.01. Москва, 2002. 140 с.

2. Белинский В. Г. Полное собрание сочинений : [в 13 т.]. Т. 10 : Статьи и рецензии: 18461848. Москва, 1956. 474 с.
3. Кавелин
К. Д.
Наш умственный строй. Статьи по философии русской истории и культуры. Москва, 1989. 656 с.

4. Дубовищкая Н. С. Роль почвенничества в формировании мировоззрения Ф. М. Достоевского // Вестник университета. 2013. № 21. С. 256-259.

5.3 ахаров В.Н. Почвенничество в русской литературе: метафора как идеологема // Проблемы исторической поэтики. 2012. № 10. С. 14-24.

6. Зеньковский В. В. История русской философии. Т. 1, ч. 2. Ленинград, 1991. 239 с.

7. Маслин М.А. О России и русской философской культуре. Философы русского послеоктябрьского зарубежья. Москва, 1990. 528 с.

8. Сакулин П. Русская литература и социализм. Москва, 1922. 504 с.

9. Гроссман Л. Три современника. Москва, 1922. $114 \mathrm{c}$.

10. Попов В. П. Учение ранних славянофилов и творчество Ф. М. Достоевского : автореф. дис. ... канд. филол. наук: 10.01.01. Ленинград, 1979. $24 \mathrm{c}$.

11. Мухина 3. 3., Канныкин С. В. Патриотизм как нравственный принцип в философии Н. Н. Страхова (1825-1896) // Научные ведомости Белгородского государственного университета. Серия: Философия. Социология. Право. 2019. T. 44, № 2. C. 1-8.

12.Страхов Н. Н. Мир как целое. Москва, 2010. $285 \mathrm{c}$.

13. Григорьев А. А. Искусство и нравственность. Москва, 2008. 584 с. irismetov@list.ru

\title{
КУЛЬТУРНАЯ ПАМЯТЬ КАК ОСНОВА ЭТНОКУЛЬТУРНОЙ ИДЕНТИЧНОСТИ
}

Аннотация. В статье рассматриваются культурно-исторические основания, особенности и проблемы формирования узбекской этнокультурной идентичности конца XX - начала XXI века, возникшие в результате процесса регионализации советского и постсоветского пространства. Постоянно возникающие возможности и риски, вызванные политическими и социально-экономическими реформами, процессами глобализации и цифровизации, вызывают изменения в формировании узбекской культурной идентичности. На примере участия (полной мере еще пока не изученного) народа Узбекистана во Второй мировой войне показана трансформация исторических дискурсов и форм репрезентации культурной памяти, преследующих, в частности, социальные цели - поиск “исторической истины”. Сквозь призму культурной памяти автором рассмотрены современные подходы к проблеме этнокультурной идентичности, роль коммеморативных практик и культурных традиций в модернизации институтов гражданского общества.

Ключевые слова: память, распад, преемник, политика, культура, номенклатура, бюрократия, коммеморативные практики, постсоветское пространство, гражданское общество.

После смены главы государства в Узбекистане в сентябре 2016 года, был запущен новый вариант транзита власти, который, как предполагалось, должен был быть осуществлен на основе но- 
вых этнокультурных традиций, связанных с контролем над институтами государства и всей политической системой. Но любой вариант транзита - альтернативный процесс, который может привести государство или в пропасть, или в тупик, или в другое политическое и этнокультурное измерение.

Рассматривая культурную память нашей страны, мы должны понимать, что «транзит власти» открывает значительное число возможностей для развития институтов гражданского общества, не исключая при этом большого количества рисков. Таким образом, данный процесс - это микс надежд, тревог, стереотипов и неоправданных амбиций. Полагаем, что если в обществе надежд больше, чем тревог, то у страны есть будущее. Если же многие люди не удовлетворены своим настоящим (а такая ситуация «прозрения» имеет место сегодня в обществе, где у старшего поколения еще в памяти хороший пример сплочения наций во Вторую мировую войну или во время Ташкентского землетрясения в апреле 1966 года), тогда вполне логично, что все меньше людей испытывают надежды по поводу своего будущего, и это уже «красная лампа» тревоги для власти.

И здесь представляются важными два момента. Во-первых, настоящий транзит власти без культурной памяти невозможен, в силу устоявшейся политической культуры и авторитета покойных лидеров Ш. Рашидова, И. Каримова и их личных качеств. Во-вторых, в настоящее время все больший акцент делается на преемственность власти, культурные традиции и обычаи, родословную преемника (на узбекском языке звучит как «ворис») и т. д. Причем всем очевидно, что новый преемник во власти столкнется с преемственностью большого количества проблем, которые не решались долгие годы. И от того, как эти проблемы будут решаться, зависит стабильность в стране, культурная память нации и дальнейшие политические и культурные перспективы тех, кто будет жить в новую эпоху в обновленной или стагнирующей стране.

Поэтому анализ нынешних событий в евразийском регионе важен не столько для преемственности существующей власти, а скорее для культурной памяти всех наций, проживающих в Узбекистане, чтобы понять содержание своего общего прошлого и будущего, выразить отношение граждан к истории, религии, языку, культуре, литературе, искусству, музыке и т. д. Потому что любая политическая сила, придя к власти (рано или поздно), будет видоизменять политическую и экономическую систему под себя. Примером тому может послужить переименование праздников. Например, в Узбекистане праздник 9 мая - День Победь переименован в День памяти и почестей.
Рассекречивание архивных документов и сотрудничество с другими странами позволили уточнить данные об участии народа Узбекистана во Второй мировой войне. Президентом страны Шавкатом Мирзиёевым 9 мая на торжественной церемонии в новом Парке Победы, посвященной 75-летию Победы над фашизмом и Дню памяти и почестей, были озвучены новые данные об участии народа Узбекистана в войне.

Глава государства не раз подчеркивал, что вклад народа Узбекистана в Великую Победу еще не до конца изучен, обращая на это внимание нашей общественности. Сегодня с удовлетворением можно отметить, что за последние годы проделана большая работа в этом направлении, в частности, он сказал, что открыты для исследователей ранее засекреченные и недоступные архивные документы и материалы. Наряду с этим усилилось сотрудничество с архивными учреждениями, музеями и фондами, учеными-историками, специалистами, общественностью республик бывшего Союза и других зарубежных стран. Благодаря проведенным научным исследованиям сегодня уже получены новые важные сведения [1].

Особо можно отметить, что «общество имеет все основания говорить о начале нового этапа в изучении нашей истории в период Второй мировой войны. Ведь, до сих пор считалось, что из 6 миллионов 551 тысячи человек, проживавших в то время в республике, в войне участвовали около 1 миллиона 500 тысяч. А как свидетельствуют последние данные, из Узбекистана были мобилизованы на фронт около 1 миллиона 951 тысячи человек. Это значит, что в борьбу против фашизма с оружием в руках вступил каждый третий узбекистанец», - сообщил Шавкат Мирзиёев [1].

«То, что в течение стольких лет вне нашего внимания оставались имена и судьбы около 451 тысячи наших соотечественников, участвовавших в ожесточенных боях, конечно, нельзя признать справедливым», - отметил он [1].

По словам главы государства, установлено, что в действующую армию были призваны более 59 тысяч узбекистанцев из республики в период раскулачивания. Ранее же считалось, что в боях погибли 396 тысяч граждан республики, ушедших на войну, на самом деле их - свыше 538 тысяч. Кроме того, не было достоверных данных о числе пропавших без вести. Сегодня точно установлено, что в годы войны пропали без вести более 158 тысяч наших соотечественников [1].

Примечательно, что в ходе научных исследований удалось прояснить вопрос награждения представителей Узбекистана боевыми орденами и медалями. До сих пор считалось, что к государственным наградам было представлено 120 тысяч 
человек. Сейчас установлено, что среди награжденных было свыше 200 тысяч солдат и офицеров из Узбекистана. Документально подтверждено, что звания Героя Советского Союза были удостоены не 280, как считалось прежде, а 301 представитель Узбекистана, 70 награждены орденом Славы всех трех степеней [1].

«Все помнят, что в суровые годы войны весь народ Узбекистана неустанно трудился с единой целью: „Все - для фронта, все - для победы!“. Наша страна превратилась в надежный тыл по обеспечению фронта. Узбекистан производил и поставлял на фронт большое количество военной техники и боеприпасов, продовольствия, одежды, лекарств и другой жизненно важной продукции. Благодаря самоотверженному труду нашего многонационального народа около 300 предприятий республики начали выпускать продукцию военного назначения. Также с прифронтовых территорий в Узбекистан был перебазирован и в короткое время пущен в эксплуатацию 151 завод. Тысячи раненых бойцов прошли лечение в организованных в нашей стране госпиталях. По последним данным, в Узбекистан были эвакуированы 1,5 миллиона человек из республик, где шла война, в том числе свыше 250 тысяч детей... Наш народ дал им кров, окружил любовью и заботой, делился подчас последним куском хлеба, проявив присущий ему высокий гуманизм» [1].

Все логично, если рассматривать культурную память как участок головного мозга, состоящий из определенного количества коммуникационных «нейронов», предназначенных для передачи, приема и обработки информации. И чем меньше таких «нейронов», тем хуже функционирует общественная система ценностей и плохо работает госаппарат, который перестает адекватно реагировать на внешние раздражители и внутренние сбои. Данный идентификационный феномен можно обозначить как «деформацию вертикали», что, возможно звучит довольно странно по отношению к системе, где долгое время, наоборот, пытаются выстраивать жесткую президентскую вертикаль власти.

Ведь в течение тысячелетий, с момента образования первых государств, система управления народом была неизменна и проста, так как втискивалась в жесткие рамки «субъект-объектных» взаимоотношений, исходя из материального достатка и доступа к культурным благам (искусству, науке, образованию и т. д.). Формы могли меняться. И довольно динамично. Но содержание властных отношений столетиями было статично консервативным, делясь на Восток и Запад. Это определяло отношение к той или иной нации и стране. Если мы говорим об иранцах Самарканда, то вспоминаем великую персидскую культуру, познакомившую человечество с творчеством Омара Хаяма, Ширази, Саади и Джалолиддина Руми, а говоря о тюркской (в т. ч. узбекской) культуре Центральной Азии, то она немыслима без великих мыслителей Алишера Навои, имама Аль Бухари или Абу Насера Аль Фараби, Абдуллы Кадыри и Ойбека. В русскую культуру и литературу навсегда вписаны величественная поэзия и проза Александра Пушкина, Михаила Лермонтова, Иосифа Бродского, Льва Толстого, Ивана Тургенева и Михаила Булгакова.

Конечно, во все времена, появлялись и исчезали разные посредники в отношениях между гениями поэтического слога и властью, но, в тоже время, внутренняя свобода творческих гениев была бесконечна, что позволяло им избегать прямых контактов между двумя измерениями добра и зла. В силу того, что посредники были, как правило, больше аффилированы с теми, кто управлял, чем выражали интересы тех, кем управляли. Исключение составляли разного рода революции и политические конфликты, которые могли сделать перезагрузку всей политической системы, что меняло характер культурной памяти нации. Это касается, например периода Серебряного века в истории русской культуры или времена «социалистического реализма» в первой половине XX века. Кстати, в социальных науках дефиниция «культурная память» и «культурная идентификация» обычно применялась для того, чтобы понять, как взаимодействуют виды сознания и систем (в т. ч. культурные, политические) с внешней средой, начиная с того, кто мы и какие мы? Вспомним хотя бы то, как мы абстрактно воспринимаем Италию и итальянцев, или же Францию и французов, абсолютно не акцентируя внимания уровень развития демократии в каждой из стран. В первую очередь, мы вспоминаем, какие культурные ценности эти нации и страны принесли человеческой цивилизации в целом.

Тем не менее, важно, понять, какие трансформации эти каналы культурной коммуникации претерпели с учетом высокой динамики изменений информационного пространства на глобальном, региональном и национальном уровнях. Ведь даже в закрытых обществах, где определено место всех и каждого его члена, возникают проблемы, связанные с арсеналом неформальных культурных коммуникаций, каждая из которых пытается найти свою точку давления на «теле» системы, в виде неформальной культуры (анекдоты, аския, частушки, самиздат и др.). И если раньше список неформальных культурных коммуникаций был довольно скудным и часто замыкался на определенной социальной страте, в расчете на прямой контакт с носителем власти, то сейчас произошел 
стремительный рост различных видов коммуникационных каналов и акторов, которые не нуждаются в реакции и оценке правящей элиты.

Этот тренд можно обозначить как «культурное антилобби», т. к. в отличие от классического лобби, участники этих коммуникационных каналов являются сторонниками публичности и транспарентности в отстаивании своих групповых культурных интересов и ценностей. Они являются инструментами «grassroots» (корни травы), под которыми в западной культурологии и политической науке подразумеваются движения (необязательно институционализированные), организованные гражданами снизу для защиты своих прав, или чтобы заявить о себе. Социальные сети лишь увеличили мобилизационный эффект такой деятельности.

Более того, интернет-мемы в социальных сетях, также являются одним из видов неформальных культурных коммуникаций, ведь некоторые из них не только могут повлиять на изменение общественного сознания (по проблемам экологии или глобальной пандемии), но и вызвать целую волну общественной поддержки или порицания, которая способна оказать влияние на изменение политического решения или поведения.

Как восклицает по этому поводу автор книги «В стране слепых» Флин Майкл Фрэнсис устами своих героев: «Понимаете, идеи - это ключ ко всему. Идеи - мы их называем «мемы» - управляют сознательным поведением людей точно также, как гены управляют инстинктами...Люди передают его друг другу, как грипп. Но вы никогда не задумывались, кто внедрил его и зачем [2, с. 32]»? Таким же образом, наша культурная память связана с идеей, чтобы оправдать наши ожидания или разочарования. И все эти глобальные тренды, прямо или косвенно, уже влияют на Узбекистан, как на весь регион под названием Евразия [3, c. 11-12].

Все это подтверждает тезисы автора книги «Конец власти» Моизеса Наима о том, что человечество вошло в эпоху трех революций: революция множества, мобильности и революция культурной ментальности [4, с. 512]. И эти глобальные тренды, прямо или косвенно, уже влияют на Узбекистан сегодня.

Ведь самой сложной задачей для любого государства является не просто очертить границы и придумать Конституцию, а заставить власть работать эффективно не только для элиты, но и для всего общества [5, с. 234]. Если это не происходит, то верхи и низы начинают жить независимо друг от друга, говоря на разных языках морали и культуры, строя разные планы на будущее и веря в разные идеалы.
Важным условием для формирования исторической памяти и культурной самоидентификации общества, является наличие элементов протогражданского общества в стране. Если в одних странах институты гражданского общества и государственные структуры развивались параллельно, то в других политических системах, к которым относятся многие постсоветские республики, государство изначально играло доминирующую роль [6, с. 288].

Не секрет, что до 2000-х годов власть в Узбекистане практически не обращала серьёзного внимания на развитие и становление неправительственного сектора. Этому есть вполне объективные причины, т. к. все 90-е годы шел процесс выстраивания политической и экономической системы после распада Советского Союза. Например, после решения генеральной конференции ЮНЕСКО о широком праздновании в 1996 году мировой общественностью 660-летия со дня рождения Амира Темура, 1996 год был объявлен Годом Амира Темура, были организованы мероприятия международного и республиканского масштаба. Кстати, это объясняет довольно интересную закономерность неравномерного распределения внимания государства к тем и ли иным институтам гражданского общества. В частности, более жесткий подход применялся по отношению к политическим партиям, профессиональным союзам и средствам массовой информации. И это имеет вполне логичное объяснение. Данные институты, с точки зрения власти, являются потенциальными политическими игроками, которые, в условиях политической монополии, должны быть под жестким контролем. Именно поэтому процесс формирования культурной памяти, как и исторической, загнали в узкие, искусственные рамки закона «Об историческом и культурном наследии». Лишь в 2019 году, в очередном Послании главы государства парламенту, была отмечена необходимость развития исторической науки и создании телеканала «История Узбекистана».

Надо признать, что в начале 2000-х годов, когда процесс политической и культурной институционализации, с точки зрения элиты, уже набрал обороты, государство решило найти место в этом процессе и неправительственному сектору. Именно в этот период были предприняты меры по созданию условий для развития негосударственных некоммерческих организаций (НHО), в т. ч. через создание ассоциации неправительственных организаций, создан Институт по поддержке и развитию гражданского общества. Все это не вызывает удивления, так как «... специфика Узбекистана состоит в том, что в условиях отсутствия развитых 
политических институтов основным источником и инициатором преобразований является государственная власть» [7, с. 112] .

Здесь можно согласиться с мнением известного узбекского ученого, академика М. Шарифходжаева, который утверждал, что «...поскольку у нас видимая и решающая роль на этапе обретения независимости принадлежала правительству, то создалось впечатление, что государство строит гражданское общество. На самом деле так и было. Хотя, многие мысли, созвучные идеям гражданского общества, вырабатывались нашими великими предками на протяжении столетий. Но, говоря об этом, надо специально обратить внимание на то, что взгляды многих из них классифицируются в качестве примеров так называемого восточного аристотелизма» [8, c. 138].

Поэтому вполне очевидно, что гражданскому обществу оставалось лишь принять ту модель, которую на первых порах предоставило ему государство. Других моделей просто не было в исторической памяти нашей государственности, начиная с известного труда «Уложения Темура». А поэтому общество вполне спокойно восприняло то, что был принят закон о государственном социальном заказе, положившем начало структурированию гражданского общества по тем направлениям, в которых было заинтересовано государство и это вполне объяснимо.

\section{Список литературы}

1. Мирзиёев Ш. М. Уважение к героизму и памяти предков: выступление Президента Республики Узбекистан на церемонии открытия парка Победы // Правда Востока. 2020. 10 мая.

2. Усманов К. История Узбекистана (19171991 годы). Ташкент, 2011. 224 с.

3. Флин М. В стране слепых. Москва: Смоленск, 1995. 142 с.

4. Сатпаев Д. Деформация вертикали. От анонимных империй до антилобби // Черная папка коммуникационного и политического апгрейда в Казахстане в условиях транзита власти. Алматы, 2019. C. 11-12.

5. Наим М.. Конец власти. От залов заседаний до полей сражений, от церкви до государства, почему управлять сегодня нужно иначе. Москва, 2016. 512 c.

6. Киященко Н. И. Эстетика - философская наука. Москва, 2005. 588 с.

7. Ирисметов Б. М. Общее и особенное в формировании политических систем в странах Центральной Азии. Ташкент, 2011. 135 с.

8. Шарифходжаев М. Формирование открытого гражданского общества в Узбекистане. Ташкент, 2002. 272 с.

\section{КУЛЬТУРНАЯ ИДЕНТИЧНОСТЬ КАК ВАЖНЫЙ ЦЕННОСТНО-СМЫСЛОВОЙ КОМПОНЕНТ САМОСОЗНАНИЯ НАРОДА В УСЛОВИЯХ ГЛОБАЛИЗАЦИИ}

Аннотация. В данной статье рассматривается культурная идентичность как важный ценностносмысловой компонент любого народа. Особый акцент в статье делается на теоретическом анализе культурной идентичности с различных методологических точек зрения, анализируются ведущие идеи исследователей в области психологии, социологии, философии и этнографии. Также в статье уделяется внимание процессу глобализации, который способствует размыванию культурных идентичностей народов России, утрате исторических корней, игнорированию культуры и языка.

Ключевые слова: культурная идентичность, культурная идентификаџия, глобализаџия, традиџионная культура, «маркер идентичности», информатизащия, традиции, этнос.

В настоящее время в нашей стране происходит активное разрушение этнокультурных границ, связанное с процессом глобализации мира. Вследствие чего со стороны общества к основам народной традиционной культуры проявляется повы- шенный интерес. Во главу угла ставятся вопросы изучения актуальных проблем культурной идентичности нации, этноса и народностей. Вместе с тем, в современном обществе, достигшем высокой стадии технологического и информационного 